\title{
Estimation of Enterprise's Investment Attractiveness in the Conditions of Development
}

\author{
ANASTASIIA MOHYLOVA ${ }^{1}$, IGOR GRYBYK ${ }^{2}$, YULIIA HLIVINSKA ${ }^{3}$, IRYNA KUDINOVA ${ }^{4}$, \\ MARHARYTA STEPANENKO ${ }^{5}$, LYUDMILA TORISHNYA ${ }^{6}$ \\ ${ }^{1}$ Department of Marketing and International Management, OLES HONCHAR DNIPRO NATIONAL UNIVERSITY, \\ DNIPRO, UKRAINE. E-mail: univ_54@meta.ua \\ ${ }^{2}$ Department of Management of Organizations, LVIV POLITECHNIC NATIONAL UNIVERSITY, LVIV, UKRAINE. \\ ${ }^{3}$ Department of International Relations and Tourism, KYIV INTERNATIONAL UNIVERSITY, KYIV, UKRAINE. \\ ${ }^{4}$ Department of Tourism, Hotel Business and Agroconsalting, NATIONAL UNIVERSITY OF LIFE AND \\ ENVIRONMENTAL SCIENCES OF UKRAINE, KYIV, UKRAINE. \\ ${ }^{5}$ Department of Economics of Industry, ODESSA NATIONAL POLYTECHNIC UNIVERSITY, ODESA, UKRAINE. \\ ${ }^{6}$ Department of Public Management and Administration, ODESSA NATIONAL POLYTECHNIC UNIVERSITY, \\ ODESA, UKRAINE.
}

\begin{abstract}
Investment attractiveness is an essential element of intensifying investment processes. The high level of investment attractiveness provides a stable inflow of investments into the country, additional revenues to the state budget, a better social environment in the country.

As a proposed innovative transformation technology, tools for digitalization of public administration are described, aimed at improving the quality of services provided, harmonizing relationships between public administration entities, and optimizing and redistributing powers from state to municipal authorities.

The article's primary goal is to develop a toolkit for assessing the investment attractiveness of an enterprise in the context of development.

The authors studied the theoretical basis, analyzed the current state of investment activity in Ukraine. Based on the analysis, a methodology for the integral assessment of the investment attractiveness of an enterprise was proposed. The proposed method has the following advantages: an integrated approach, coverage of a large set of indicators and coefficients, accurate mathematical calculation of the indicator, which serves as a criterion for assessing investment attractiveness, allows you to consider the dynamics of indicators over several years.
\end{abstract}

Keywords: Development, Enterprise, Investment Attractiveness

JEL Classification: D92, D90, D81 


\section{1. introduction.}

The main prerequisite for ensuring socio-economic development in the country, increasing competitiveness and improving the financial condition of the domestic economy, strengthening their competitive position in domestic and foreign markets is the intensification of investment activities based on finding attractive areas and objects of effective investment of available free resources.

Currently, the aspects of assessing the investment attractiveness of regions [1-4], industrial sectors [5-7] and various investment programs [8-11] have been studied more extensively. However, in the context of learning the investment attractiveness of enterprises to this day, there is no single theoretical and methodological basis; this is manifested in the absence of a single concept of the term "investment attractiveness of an enterprise" and a single methodology for its assessment.

A critical analysis of known methodological approaches to assessing the investment attractiveness of enterprises shows the following:

1) their practical implementation is complicated due to the high requirements for the volume of the primary information base, the preparation and processing of which requires additional special research, significant time and money;

2) the modern methodology for assessing investment attractiveness is not focused on management but is only a tool for fragmentary static fixation of the size and level of use of financial resources of the enterprise;

3) methods of assessing investment attractiveness, as a rule, do not take into account the degree of involvement of the enterprise in the process of investment development of the country (region, industry) and the specifics of its activities (scale, territorial and sectoral affiliation) $[5 ; 9]$.

Thus, the article aims to develop tools for assessing the investment attractiveness of the enterprise in terms of development.

\section{Theoretical basis}

Usually, the concept of "investment attractiveness" means the presence of conditions and factors that influence the investor's decision-making. Investment attractiveness is built under the influence of many factors, but most of them are reflected in the enterprise's financial condition. Analysis of the financial condition of an enterprise can be used as a tool to study the level of investment attractiveness. The attraction of deposits is directly related to the level of investment attractiveness of the enterprise, which depends on a large number of interrelated factors.

Existing approaches to the essence of the investment attractiveness of an enterprise can be systematized and grouped into four groups according to the following criteria (Fig. 1).

Thus, the investment attractiveness of an enterprise is an indicator of the aggregate value of an enterprise, which is a set of objective and subjective characteristics necessary to satisfy the interests of all participants in the investment process and allows one to characterize its prospects and taking into account the cumulative influence of factors. Investment attractiveness is characterized not only by the stability of its financial condition, the level of financial results but also by the competitiveness of the products, the degree of risky investments, and the possibility of enhancing innovation, management, and the enterprise's image. All these elements must be taken into account when assessing the investment attractiveness of an enterprise, along with internal indicators [2; 4].

Thus, the investment attractiveness of an enterprise is an indicator of the aggregate value of an enterprise, which is a set of objective and subjective characteristics necessary to satisfy the interests of all participants in the investment process and allows one to characterize its prospects and taking into account the cumulative influence of factors. Investment attractiveness is characterized not only by the stability of its financial condition, the level of financial results but also by the competitiveness of the products, the degree of risky investments, and the possibility of enhancing innovation, 
management, and the enterprise's image. All these elements must be taken into account when assessing the investment attractiveness of an enterprise, along with internal indicators.

Figure 1. Approaches to the essence of the investment attractiveness of an enterprise

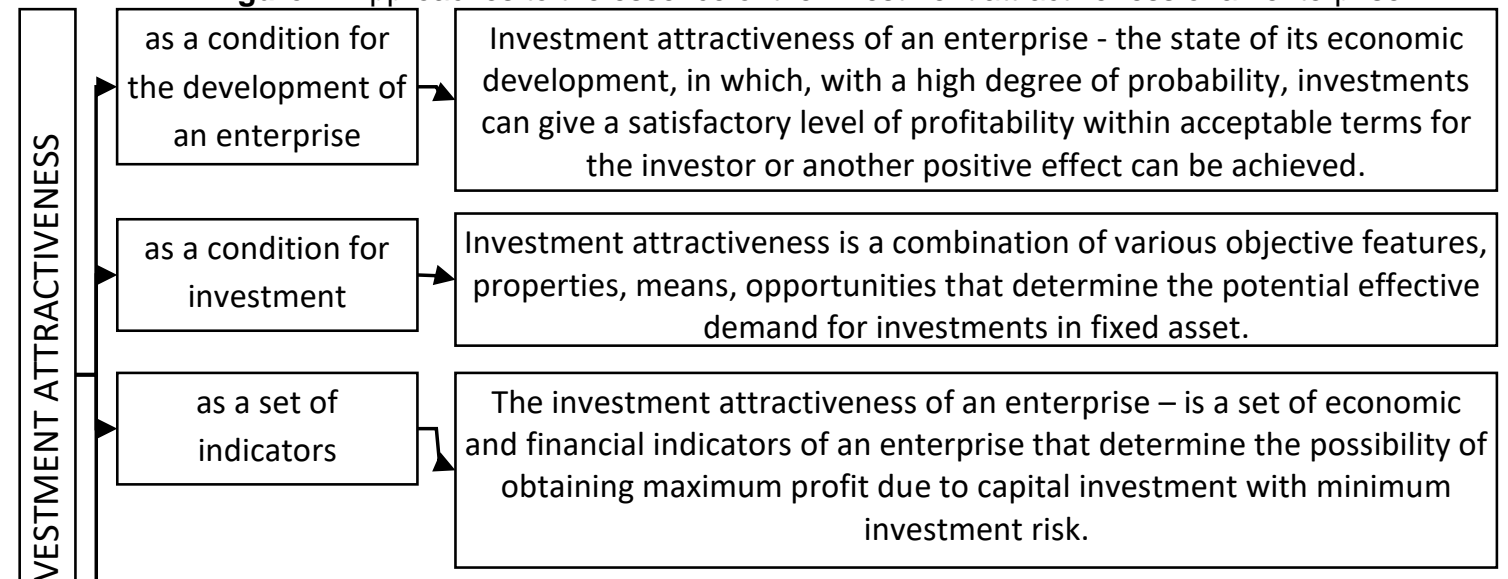
as an indicator of
investment efficiency Investment efficiency determines investment attractiveness, and
investment attractiveness determines investment activity. The higher
the investment efficiency, the higher the level of investment
attractiveness and the larger the investment activity, and vice versa.

Increasing the efficiency of the enterprise and its investment attractiveness can be carried out by:

- creating new production facilities at points with the most accessible raw material opportunities and in proximity to consumers of finished products;

- implementation of innovative projects;

- expansion and differentiation of the scale of production;

- The modernization of production and its technical re-equipment with resource-saving equipment and equipment consume fewer costs [9; 12].

The investment attractiveness of an enterprise is a generalizing indicator of an investment object in terms of investment profitability, development prospects and the level of investment risks.

To make decisions on the implementation of investment investments is necessary to compare the expected positive income in the future with the ongoing costs of capital investments. The applied significance of the issues regarding the determination of the investment attractiveness of enterprises is beyond doubt since, without investment in business entities, the growth of the economy and its stabilization is not possible. The solution to this problem ensures the viability of the enterprise as a whole.

Financial analysis, as the main mechanism that ensures the financial stability of an enterprise and an assessment of its attractiveness for potential investors, is the central link in the methodology for determining investment attractiveness. Its main purpose is to study the problems that arise when assessing the financial attractiveness of an enterprise for an investor. In this regard, the aspects of the analysis of the enterprise's financial condition are considered, the level of profitability, creditworthiness, efficiency, and financial stability is assessed. The result of the financial analysis of the enterprise is the determination of the main directions of increasing the investment attractiveness of the analyzed enterprise.

\section{Analytical basis}

If we consider the investment activity of Ukraine in the context of regions, then the most active are the City of Kyiv (27.6\%), Dnipropetrovsk (18.6\%) and Donetsk (9.6\%) (Table 1). 
Table 1. Capital investments by types of economic activity of industry by regions in 2020 (according to the statistics service of Ukraine [13])

\begin{tabular}{|c|c|c|c|c|c|c|c|c|}
\hline & & & & & & & & \\
\hline REGION & MINING AND & QUARRYING & MANUFAC & IURING & $\begin{array}{r}\text { ELECTRICITY } \\
\text { AND AIR CO }\end{array}$ & $\begin{array}{l}\text { GAS, STEAM } \\
\text { IDITIONING } \\
L Y\end{array}$ & $\begin{array}{r}\text { WATEF } \\
\text { SEWERA } \\
\text { MANAGE } \\
\text { REME }\end{array}$ & $\begin{array}{l}\text { SUPPLY, } \\
\text { IE, WASTE } \\
\text { MENT AND } \\
\text { IATION }\end{array}$ \\
\hline & thsd.UAH & $\begin{array}{l}\text { in } \% \text { to the } \\
\text { total in } \\
\text { the region }\end{array}$ & thsd.UAH & $\begin{array}{l}\text { in \% to the } \\
\text { total in } \\
\text { the region }\end{array}$ & thsd.UAH & $\begin{array}{l}\text { in } \% \text { to the } \\
\text { total in the } \\
\text { region }\end{array}$ & thsd.UAH & $\begin{array}{l}\text { in } \% \text { to the } \\
\text { total in the } \\
\text { region }\end{array}$ \\
\hline UKRAINE & 44755568 & 29,2 & 69328075 & 45,2 & 36102093 & 23,6 & 3135297 & 2,0 \\
\hline VINNYTSYA & 399683 & 11,7 & 2675412 & 78,3 & 310029 & 9,1 & 30155 & 0,9 \\
\hline VOLYN & $c-$ & $c-$ & 5292982 & 92,0 & 439331 & 7,6 & $c-$ & $c-$ \\
\hline DNIPROPETROVSK & 14558356 & 51,1 & 11647843 & 40,9 & 2033393 & 7,1 & 244722 & 0,9 \\
\hline DONETSK & 4455205 & 30,3 & 9492053 & 64,5 & 609592 & 4,1 & 161988 & 1,1 \\
\hline ZHYTOMYR & c- & $c-$ & 1091906 & 50,4 & c- & $c-$ & 351002 & 16,2 \\
\hline ZAKARPATTYA & $c-$ & $c-$ & 909759 & 59,0 & $c-$ & $c-$ & 29569 & 1,9 \\
\hline ZAPORIZHZHYA & 1115596 & 18,8 & 4134476 & 69,8 & 560510 & 9,5 & 110391 & 1,9 \\
\hline IVANO-FRANKIVSK & 114527 & 6,0 & 1236263 & 64,6 & 539904 & 28,2 & 23372 & 1,2 \\
\hline KYIV & 22591 & 0,3 & 2108914 & 28,1 & 5122777 & 68,4 & 240418 & 3,2 \\
\hline KIROVOHRAD & 94961 & 6,4 & 1034361 & 69,4 & 284305 & 19,1 & 77845 & 5,2 \\
\hline LUHANSK & 5246 & 0,9 & 384438 & 65,2 & 181553 & 30,8 & 18367 & 3,1 \\
\hline LVIV & 172282 & 2,9 & 3889631 & 65,0 & 1700999 & 28,4 & 220439 & 3,7 \\
\hline MYKOLAYIV & 89131 & 4,5 & 1392535 & 70,1 & 449950 & 22,7 & 54025 & 2,7 \\
\hline ODESA & $c-$ & c- & 1774390 & 43,4 & 2286613 & 55,9 & $c-$ & c- \\
\hline POLTAVA & 7066612 & 71,8 & 2161704 & 22,0 & 505720 & 5,1 & 109660 & 1,1 \\
\hline RIVNE & 125296 & 11,4 & 596421 & 54,0 & 359682 & 32,6 & 22446 & 2,0 \\
\hline SUMY & $c-$ & c- & 1465427 & 78,9 & 358157 & 19,3 & $c-$ & c- \\
\hline TERNOPIL & 70386 & 4,8 & 741600 & 50,2 & 451162 & 30,5 & 215076 & 14,5 \\
\hline KHARKIV & 26174 & 0,5 & 3644031 & 72,2 & 1145925 & 22,7 & 233626 & 4,6 \\
\hline KHERSON & $c-$ & c- & 340290 & 76,5 & $c-$ & c- & 65450 & 14,7 \\
\hline KHMELNYTSKIY & 66758 & 2,6 & 1833723 & 70,3 & 683561 & 26,2 & 25532 & 1,0 \\
\hline CHERKASY & $c-$ & c- & 1021951 & 93,1 & $c-$ & $c-$ & 46644 & 4,2 \\
\hline CHERNIVTSI & 22583 & 3,9 & 188608 & 32,6 & 350165 & 60,6 & 16403 & 2,8 \\
\hline CHERNIHIV & $c-$ & $c-$ & 1067724 & 74,0 & 278186 & 19,3 & $c-$ & c- \\
\hline CITY OF KYIV & 16075627 & 38,0 & 9201633 & 21,8 & 16303071 & 38,6 & 687028 & 1,6 \\
\hline
\end{tabular}

Note. "c -» Data are not published in order to ensure compliance with the requirements of the Law of Ukraine On the State Statistics regarding confidentiality of statistical information.

When evaluating investment activity within the economic sectors of enterprises, it is necessary to consider this aspect in more detail (Fig. 2).

So, the leader in terms of the volume of financial investments is Manufacturing (16.5\%); Public administration and defence (13.3\%); Mining and quarrying (10.7\%).

However, let's consider the context of each source. The leader of investing by state budget funds is Public administration and defence $(81.3 \%)$, by own funds of enterprises and organizations is Manufacturing (16.5\%), by funds of investment companies, funds is Construction (72.5\%), by funds of non-resident investors are Administrative and support service activities (40.8\%) and Manufacturing (40.5\%). 
Figure 2. Capital investments by financing sources by types of economic activity in 2020 (developed according to the statistics service of Ukraine [13])

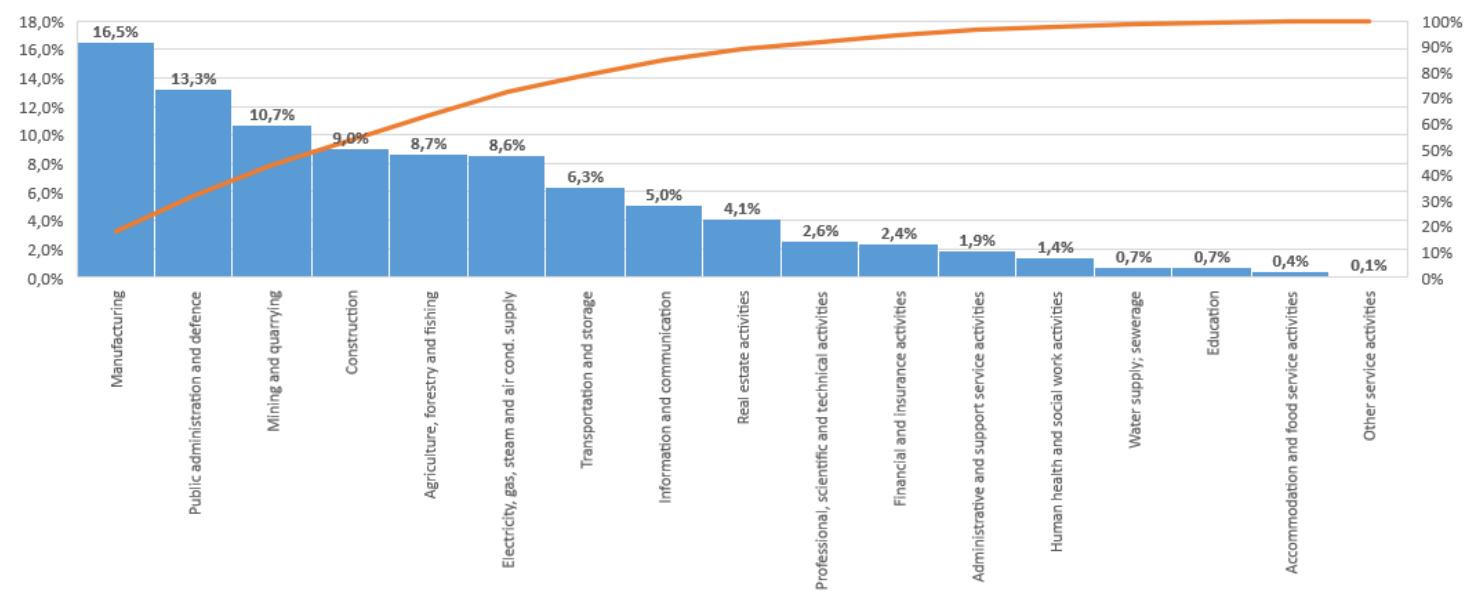

\section{Results and discussion aspects}

Theoretical and analytical analysis showed that Ukrainian enterprises are ready for investment, especially in conditions of growth, but there are general and specific features:

- the reporting of Ukrainian enterprises does not always correspond to the actual state of affairs, since often the owners, for various reasons, divide the business into several unrelated enterprises;

- new indicators have appeared in society that characterize the activities of the enterprise, which are dictated by large-scale digitalization, the recycling economy, the intellectualization of production, etc.

That is why we propose to determine the investment attractiveness of an enterprise by calculating an integral indicator, which is based on both the usual financial indicators of the enterprise's activities and innovative ones.

In general, for clarity in making management decisions, we propose to consider investment attractiveness as an integral coefficient of 3 groups of indicators - those that are calculated on the basis of financial statements, qualitative indicators and those that show the innovativeness of the enterprise:

$$
K_{I A}=\prod X_{f i} * X_{q} * X_{i n} .
$$

In general, the level of investment attractiveness of an enterprise can be determined by calculating the final coefficient of investment attractiveness using the formula:

$$
K_{I A}=\prod \frac{x_{i j}}{x_{\max }} \leq 1
$$

where $K_{I A}$ - coefficient of investment attractiveness;

$x_{i j}$ - analysis in points of the current indicator of the enterprise;

$x_{\max }-$ the maximum score for this indicator.

The analysis of the final indicator of investment attractiveness is compared with the following digital values:

0.80 - 1.00 - high level of investment attractiveness;

0.40 - 0.79 - average level of investment attractiveness;

0.20 - 0.29 - low level of investment attractiveness;

$0.00-0.19$ - the enterprise is not attractive for investment. 
We offer the following indicators reflecting the investment attractiveness (Table 2). We will also immediately show the benchmarks of these indicators.

Table 2. Indicators reflecting the investment attractiveness (developed by the authors)

\begin{tabular}{|c|c|c|}
\hline Index & Indicator & $\begin{array}{l}\text { Reference } \\
\text { value }\left(x_{\max }\right)\end{array}$ \\
\hline \multicolumn{3}{|c|}{ Classic financial indicators, usually calculated based on financial statements $\left(\mathrm{x}_{\mathrm{fi}}\right)$} \\
\hline \multirow{4}{*}{ Profitability } & Return on sales, $\%$ & $>20$ \\
\hline & Return on non-current assets, $\%$ & $>20$ \\
\hline & Return on current assets, $\%$ & $>15$ \\
\hline & Return on equity & $>45$ \\
\hline \multirow{4}{*}{ Liquidity } & Inventory liquidity & $>0,5$ \\
\hline & Current liquidity & $>1,3$ \\
\hline & Critical liquidity & $>1$ \\
\hline & Absolute liquidity & $>0,3$ \\
\hline \multirow{9}{*}{ Financial stability } & Own working capital security ratio,\% & $>22$ \\
\hline & Autonomy ratio,\% & \\
\hline & Coverage ratio of available assets of all financial liabilities & $>2$ \\
\hline & General solvency ratio & $>0,7$ \\
\hline & Financial Risk Ratio & $<0,5$ \\
\hline & Dependency ratio & $<0,5$ \\
\hline & Debt capital concentration ratio & 0,9 \\
\hline & Equity capital flexibility ratio & $>0,5$ \\
\hline & Long-term borrowing ratio & 0 \\
\hline \multicolumn{2}{|r|}{ Qualitative indicators $\left(x_{q}\right)$} & $x_{\max }=3$ \\
\hline \multicolumn{3}{|c|}{ Assessment of the area of activity of the organization and the market for manufactured products } \\
\hline \multirow{3}{*}{$\begin{array}{l}\text { Segment and market } \\
\text { share }\end{array}$} & The organization is one of the market leaders. & 3 \\
\hline & The organization has an average market share. & 2 \\
\hline & The organization has a negligible market share & 1 \\
\hline \multirow{3}{*}{$\begin{array}{l}\text { Sensitivity of products } \\
\text { to changes in market } \\
\text { conditions, price and } \\
\text { non-price factors of } \\
\text { demand }\end{array}$} & Products have a low sensitivity to demand (essential goods). & 3 \\
\hline & The product has an average sensitivity. & 2 \\
\hline & $\begin{array}{l}\text { Products are highly sensitive (as a result of changes in fashion, product } \\
\text { prices and other factors) }\end{array}$ & 1 \\
\hline \multirow{3}{*}{ Price level } & $\begin{array}{l}\text { Prices correspond to market prices; the applied pricing policy stimulates } \\
\text { sales. }\end{array}$ & 3 \\
\hline & $\begin{array}{l}\text { Prices generally correspond to market prices, but there is no pricing } \\
\text { strategy. }\end{array}$ & 2 \\
\hline & Prices are higher than market prices, no justification for prices & 1 \\
\hline \multirow{3}{*}{$\begin{array}{l}\text { Competitive } \\
\text { environment }\end{array}$} & $\begin{array}{l}\text { There is practically no competition (low - less than } 5 \text { organizations, the } \\
\text { borrower is a monopolist). }\end{array}$ & 3 \\
\hline & The competition is average ( 5 to 10 competitors). & 2 \\
\hline & The number of competitors is high (10 or more) & 1 \\
\hline \multirow{3}{*}{$\begin{array}{l}\text { The presence in the } \\
\text { industry and the } \\
\text { region of foreign } \\
\text { competing companies }\end{array}$} & There are no foreign companies competing. & 3 \\
\hline & $\begin{array}{l}\text { There are foreign competing companies with the level of technologies } \\
\text { corresponding to the technologies of the analyzed enterprise. }\end{array}$ & 2 \\
\hline & $\begin{array}{l}\text { There are foreign competitors with more advanced production and sales } \\
\text { technologies }\end{array}$ & 1 \\
\hline \multicolumn{3}{|c|}{ Assessing the reputation of the organization and its management } \\
\hline \multirow{3}{*}{$\begin{array}{l}\text { Credit history of the } \\
\text { organization }\end{array}$} & Positive reputation for all previous obligations to the borrower & 3 \\
\hline & $\begin{array}{l}\text { Insignificant violations in repayment of obligations by the borrower in } \\
\text { previous periods or lack of credit history }\end{array}$ & 2 \\
\hline & Negative credit history from previous contacts with the organization & 1 \\
\hline \multirow{3}{*}{$\begin{array}{l}\text { Assessment of the } \\
\text { organization by } \\
\text { suppliers, consumers } \\
\text { and other market } \\
\text { participants (business } \\
\text { reputation) }\end{array}$} & High reputation, strict adherence to all delivery and payment terms & 3 \\
\hline & $\begin{array}{l}\text { Individual violations comply with payment deadlines, which are not regular, } \\
\text { as well as compliance with specific rules and regulations }\end{array}$ & 2 \\
\hline & $\begin{array}{l}\text { Systematic non-compliance with payment terms, violation of established } \\
\text { rules by the organization }\end{array}$ & 1 \\
\hline $\begin{array}{l}\text { Personal qualities of } \\
\text { top managers of the }\end{array}$ & $\begin{array}{l}\text { High authority among leaders in the business community (if necessary, they } \\
\text { personally enter into negotiations about adjusting the terms or conditions }\end{array}$ & 3 \\
\hline
\end{tabular}




\begin{tabular}{|c|c|c|}
\hline \multirow[t]{3}{*}{ company } & for fulfilling obligations). & \\
\hline & $\begin{array}{l}\text { Good professional qualities, knowledge of modern methods of industrial } \\
\text { and financial management, but little popularity in the business community }\end{array}$ & 2 \\
\hline & $\begin{array}{l}\text { Persons unknown to the business community, a manager without serious } \\
\text { administrative work skills and experience in obtaining credit resources }\end{array}$ & 1 \\
\hline \multicolumn{3}{|c|}{ Analysis of the economic potential of the enterprise } \\
\hline \multirow{3}{*}{ Labour productivity } & High, in line with the industry average. & 3 \\
\hline & Medium, insignificant growth trends & 2 \\
\hline & Below the industry average & 1 \\
\hline \multirow{3}{*}{$\begin{array}{l}\text { The depreciation rate } \\
\text { of the active part of } \\
\text { fixed assets }\end{array}$} & Less than $20 \%$. & 3 \\
\hline & From 20 to $50 \%$. & 2 \\
\hline & More than $50 \%$ & 1 \\
\hline \multirow{3}{*}{$\begin{array}{l}\text { Material yield of } \\
\text { products }\end{array}$} & $\begin{array}{l}\text { Compliance with the average industry level and even slightly higher than } \\
\text { that of the main competitors }\end{array}$ & 3 \\
\hline & Compliance with the level of the main competitors & 2 \\
\hline & Significantly below the industry average & 1 \\
\hline \multirow{3}{*}{$\begin{array}{l}\text { Profit before tax and } \\
\text { revenue ratio }\end{array}$} & Increased significantly during the reporting period. & 3 \\
\hline & Almost did not change during the reporting period. & 2 \\
\hline & Decreased significantly during the reporting period & 1 \\
\hline \multirow{3}{*}{$\begin{array}{l}\text { The success of the } \\
\text { company's } \\
\text { management }\end{array}$} & $\begin{array}{l}\text { High, the organization has significantly improved social, operational and } \\
\text { financial performance. }\end{array}$ & 3 \\
\hline & Average, fundamental indicators have changed slightly. & 2 \\
\hline & Poor, primarily social, operational and financial performance deteriorated. & 1 \\
\hline \multirow{3}{*}{ Staff turnover } & Low, the organization has a stable team. & 3 \\
\hline & Average, management changes insignificantly. & 2 \\
\hline & High, including top and middle management & 1 \\
\hline \multirow{3}{*}{$\begin{array}{l}\text { Organizational } \\
\text { structure }\end{array}$} & $\begin{array}{l}\text { In all respects, it corresponds to the business and the specifics of the } \\
\text { organization. }\end{array}$ & 3 \\
\hline & There are deficiencies in the organizational structure. & 2 \\
\hline & $\begin{array}{l}\text { Does not correspond to the organization's business and modern conditions } \\
\text { of the economic environment }\end{array}$ & 1 \\
\hline \multirow{3}{*}{$\begin{array}{l}\text { Uniformity (cyclical } \\
\text { and seasonal) receipt } \\
\text { and expenditure of } \\
\text { funds }\end{array}$} & The production is not seasonal; the cash flow is even. & 3 \\
\hline & Production is seasonal in nature; in the seasonal cycle, cash flows are even. & 2 \\
\hline & There is no uniformity in the receipt and expenditure of funds & 1 \\
\hline \multirow{3}{*}{$\begin{array}{l}\text { Dependence on large } \\
\text { buyers and suppliers }\end{array}$} & Absent & 3 \\
\hline & It is possible to replace/stop working & 2 \\
\hline & Unable to replace/stop working & 1 \\
\hline \multicolumn{3}{|c|}{ Indicators of innovativeness of the enterprise $\left(x_{i n}\right)$} \\
\hline \multirow{3}{*}{$\begin{array}{l}\text { Level of innovation } \\
\text { activity }\end{array}$} & $\begin{array}{l}\text { The organization is systematically engaged in developing and transforming } \\
\text { scientific knowledge into new types of products, the use of innovative } \\
\text { achievements in various technological processes. }\end{array}$ & 3 \\
\hline & $\begin{array}{l}\text { The organization is just beginning to master innovative achievements until it } \\
\text { has introduced them into the production of products. }\end{array}$ & 2 \\
\hline & $\begin{array}{l}\text { The organization's business is in the area where it is possible to use the } \\
\text { innovative potential, but it does not. }\end{array}$ & 1 \\
\hline \multirow{3}{*}{$\begin{array}{l}\text { Availability and use of } \\
\text { information that gives } \\
\text { it an advantage over } \\
\text { others }\end{array}$} & $\begin{array}{l}\text { The organization possesses and uses information that gives it advantages } \\
\text { over others. }\end{array}$ & 3 \\
\hline & The organization does not fully exploit its informational advantages. & 2 \\
\hline & The organization does not have this information, while competitors have it & 1 \\
\hline
\end{tabular}

We believe that when developing a methodology for analyzing investment attractiveness, several characteristics of target companies should be taken into account:

- growth trajectory:

1) companies with stable growth: growth rates of profits and revenues at or not lower than the nominal growth rates of the economy in which they operate;

2) companies with moderate growth: profit and revenue growth rates moderately higher than nominal economic growth rates (moderate growth rates - $8-10 \%$ of nominal economic growth); 
3) companies with fast growth: the growth rate of profits and revenues far exceeds the rate of nominal economic growth.

- source of growth:

1) the nature of the competitive advantage (for example, a well-known brand is more likely to generate growth over long periods); The "first-mover advantage" collapses much faster;

2) the competence of the company's management largely determines the sustainability and stability of growth;

3) the presence of barriers to entry into the industry (the higher, the greater the chance to maintain stable growth).

For greater detail and accuracy in calculating investment attractiveness, it is possible to determine the importance of each indicator / each group of indicators, which will be a further field of study. Also, the list of proposed indicators can and should be expanded depending on the specifics of the enterprise, changes in the external environment and other factors.

\section{Conclusion}

Thus, the assessment of the enterprise's investment attractiveness is a prerequisite for choosing a further financial strategy for its development, justifying the feasibility of capital investment. Rational management decisions should be aimed at improving the quality of investment potential of the enterprise by coordinated improvement of the proportions between its components, dynamic and flexible development of the internal structure and strengthening the problem orientation following the system of strategic development goals. The proposed evaluation method allows bringing together a single system of measurement and evaluation of heterogeneous quantitative and qualitative parameters that characterize the components of economic entities' investment attractiveness to obtain an objective picture of the state and effectiveness of existing investment potential and investment risk. Based on the integrated indicators calculated by this method, it is possible to investigate the compliance of the current investment activity of the enterprise to the investment potential to identify ways to reconcile them.

The proposed method will allow the investor to choose from several companies the most investment-attractive.

\section{References}

1. Usov, A.V., Niekrasova, L.A., Dašić, P.V. (2020). Management of development of manufacturing enterprises in decentralization conditions. Management and Production Engineering Review, 11(4), pp. 46-55.

2. Fedorenko, A., Kovalenko, N. (2020). Investment attractiveness of regions of Ukraine. Market Infrastructure. DOI: 10.32843/infrastruct39-45

3. Petrova, S., M.V. Aleksandrov, M., V.V. Ashmarin, V., Evseev, A. (2019). Comparative analysis of investment attractiveness of regions. Fundamental research, No 12, pp. 160-164. DOI: $10.17513 /$ fr. 42640

4. Jacek Binda, Maryna Prokopenko, Andrii Ramskyi, Olena Shuplat, Liudmyla Halan and Dmytro Mykhaylenko (2020). Assessment of Investment Attractiveness of Industrial Enterprises, International Journal of Management, 11 (2), pp. 27-35.

5. Gutkevych, S. (2019). Investment attractiveness of industries: features and trends. Baltic Journal of Economic Studies, 5(3):50 DOI: 10.30525/2256-0742/2019-5-3-50-58

6. Chukurna, O., Niekrasova, L., Dobrianska, N., Izmaylov, Ya., Shkrabak, I., Ingram, K. (2020). Formation of methodical foundations for assessing the innovative development potential of an industrial enterprise. Naukovyi Visnyk Natsionalnoho Hirnychoho Universytetu, 2020(4), pp. 146151. 
7. Meylanov, I., Esetova, A. (2015). Main increase the investment attractiveness of industrial construction. Herald of Dagestan State Technical University Technical Sciences, 38(3), pp. 192202. DOI: 10.21822/2073-6185-2015-38-3-192-202

8. Bondareva, T. (2021). Investment attractiveness: essence and approaches to assessment. Business Strategies, 9(1), pp. 9-12. DOI: 10.17747/2311-7184-2021-1-9-12

9. Nikishina, O., Morgunova, T. (2016). Assessment of investment attractiveness of real estate objects. DOI: 10.21285/2227-2917-2016-2-80-86

10.Afanas'eva, K., Borisenko, A., Ptuhina, I. (2019). The mechanism for assessing the investment attractiveness of assets in progress building. DOI: 10.18411/lj-04-2019-149

11.Splender, V., Orlov, A. (2019). A comprehensive assessment of the investment attractiveness of a startup. DOI: 10.15862/16ECOR319

12.Hutsaliuk, O., Koval, V., Tsimoshynska, O., Koval, M., Skyba, H. (2020). Risk Management of Forming Enterprises Integration Corporate Strategy. TEM Journal, 9(4), pp. 1514-1523.

13.State Statistics Service of Ukraine http://www.ukrstat.gov.ua/ 